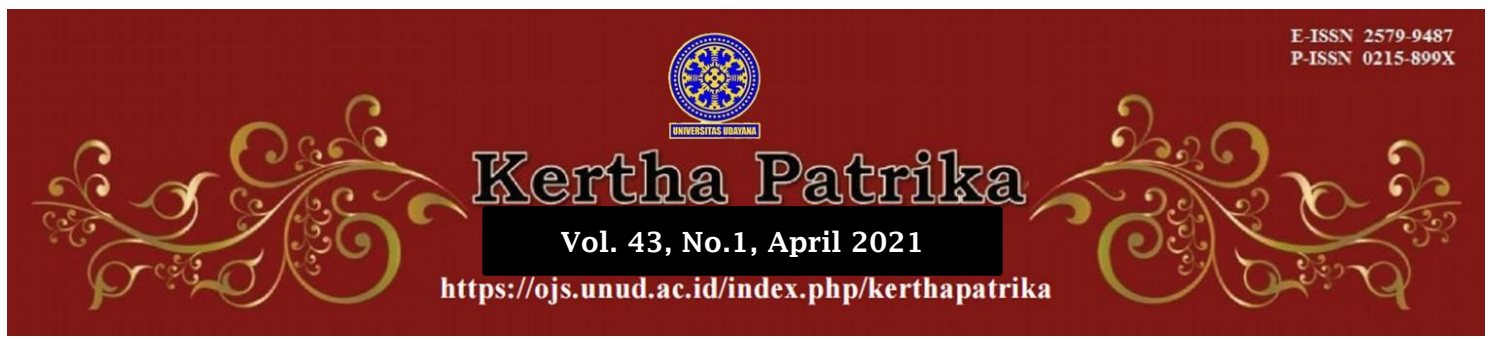

\title{
Local Certification: \\ Genetically Modified Organisms and Commercialization
}

\section{Bayu Sujadmiko', HS Tisnanta², Orima Melati Davey ${ }^{3}$}

${ }^{1}$ Fakultas Hukum Universitas Lampung, E-mail: bayu.sujadmiko@fh.unila.ac.id

${ }^{2}$ Fakultas Hukum Universitas Lampung, E-mail: s.nymus@yahoo.co.id

${ }^{3}$ Magister Ilmu Hukum Fakultas Hukum Universitas Lampung, E-mail: oridavey23@gmail.com

\begin{tabular}{l}
\hline Info Artikel \\
\hline Submitted : $21^{\text {st }}$ April 2020 \\
Accepted : $18^{\text {th }}$ January 2021 \\
Published : $28^{\text {th }}$ April 2021 \\
Keywords : \\
Genetically Modified \\
Organism; Certification; Local \\
Government; \\
Product \\
\\
Corresponding Author: \\
Bayu Sujadmiko, E-mail: \\
bayu.sujadmiko@fh.unila.ac.id \\
\\
DOI : \\
10.24843/KP.2021.v43.i01.p0 \\
$\mathbf{1}$
\end{tabular}

\begin{tabular}{l}
\hline Abstract \\
\hline Local government requires a regulatory framework as a base of \\
Genetically Modified Organisms' (GMO) development and \\
expansion in order to support food sovereignty. In regions of \\
Indonesia, GMO products could be strengthened through local \\
certification. The involvement of the government is vital in \\
supporting the economical activities of entrepreneurs in certain \\
regions. Researchers are interested in further discussion on, "Local \\
Certification: Genetically Modified Organisms' \\
Commercialization". The studies focus on the urgency for local \\
certification in GMO products and the commercialization of local \\
certification towards GMO Products of region in Indonesia. This \\
is normative research through a statute approach, which concerns \\
legal basis for local government authority regarding agricultural \\
products' affairs. The research suggested that urgency for local \\
certification in every region is very much needed to bolster food \\
production with GMO technology base as part of the geographical \\
index product. In the implementation amongst society, the product \\
could be supervised and developed to enhance local and national \\
economic activities by paying attention to the quality of \\
genetically modified products and its food safety. GMO \\
commercialization is still constrained by permit on feed, food and \\
environmental safety. Therefore, the Indonesian Government's \\
protection on GMO product commercialization is required, both \\
from national and local governments through a local certification. \\
The practice upon food local certification is implemented in several \\
regions of Indonesia, such as West Sumatra by establishing an \\
institution; Kebumen Regency by forming a food certification \\
related regulation and Palembang City also by applying food \\
certification.
\end{tabular}




\section{Introduction}

Food is a basic necessity for humans around the world; hence food availability is an important aspect to realize food security. ${ }^{1}$ However, the world population continues to increase every year and demand for food will also rise.The Food and Agriculture Organization $(\mathrm{FAO})^{2}$ reveals that the food crisis and hunger are currently overshadowing the people's lives globally. ${ }^{3}$ FAO predicted world food scarcity in 2050 that is caused by the increased world population that reached 9 million people. FAO also expected, approximately 800 million of the population will lack food access. ${ }^{4}$ On one side, the agricultural sector as a food provider is asked to be more productive in balancing $70 \%$ raise in world food demands. ${ }^{5}$ This fact shows that every country in the world has challenges to fulfill food for their citizens through their agricultural sector in order to prevent food scarcity.

Every country must guarantee the right of their citizens to provide (at least) decent food through a sustainable and environmental-friendly method; this is called "food sovereignty". ${ }^{6}$ In Indonesia, food sovereignty is a main strategy to reach food safety as one of the national food development goals. ${ }^{7}$ Various efforts had been done to realize food sovereignty, namely by implementing biotechnology.

Alongside the improvement of science and communication-technology, a new technology emerged from the biological system, thus known as biotechnology. ${ }^{8}$ This particular technology influences a lot of human lives sectors from food, medicine, health, weapons, industries and many more. ${ }^{9} \mathrm{FAO}$ stated that biotechnology has a role in the

${ }^{1}$ Farid, Abdul., Romadi, Ugik., Witono, Djoko. (2018). Faktor- Faktor yang Mempengaruhi Adopsi Petani dalam Penerapan Sistem Tanam Jajar Legowo di Desa Sukosari Kecamatan Kasembon Kabupaten Malang Provinsi Jawa Timur. Jurnal Penyuluhan, 4 (1), 27-32, doi: 10.25015/ penyuluhan.v14i1.19226, p. 27.

2 Food and Agriculture Organization (FAO) is a special United Nation's Agency that leads international efforts to tackle hunger. FAO's first function is to collect, analyze and interpret information relation to nutrition, food and agriculture. FAO Office for Corporate Communication. (2019). FAO Publication Catalogue 2019 March. Italy: FAO Publication, p. 5.

${ }^{3}$ Mudrieq, Sulfitri Hs. (2014). Problematika Krisis Pangan Dunia dan Dampaknya Bagi Indonesia. Jurnal Academica Fisip Untad, 6 (2), 1287-1302, p. 1288.

${ }^{4}$ Felicia Wu, The Future of Genetically Modified Crops Lessons from the Green Revolution, Santa Monica: Rand Corporation, 2004, pg. 4.

${ }^{5}$ Dinas Pertanian, Perikanan, dan Kehutanan Kota Pontianak. Tanaman Transgenik, Solusi atau Polusi?. Available from http:// pertanian.pontianakkota.go.id/artikel/23-tanaman-transgeniksolusi-ataupolusi.html. (Accessed on 5 January 2018).

6 Bernstein, Henry., Bachriadi, Dianto. (2014). Tantangan Kedaulatan Pangan, Bandung: ARC Books, p. 11.

7 Syahyuti, et.al. (2015). Kedaulatan Pangan Sebagai Basis Untuk Mewujudkan Ketahanan Pangan Nasional. Forum Penelitian Agro Ekonomi, 33 (2), 95-109, doi: 10.21082/fae.v33n2.2015.95109, p. 106.

${ }^{8}$ Biotechnology is a technology that uses biological systems (process) to obtain useful goods and services for humankind's prosperity. Sutarno. (2016). Rekayasa Genetik Dan Perkembangan Bioteknologi di Bidang Peternakan. Proceeding Biology Education Conference, 13 (1), 23-27, p. 23.

${ }^{9}$ Rifkin, Jeremy. (1998). The Biotech Century: How Genetic Commerce Will Change the World, London: Phoenix, p. 2 
agricultural sector to solve food production issues in developing countries. ${ }^{10}$ One of biotechnology implementation's results is Genetically Modified Organisms or GMO.

GMO includes sundry traditional processes such as the makings of beer, bread, wine, cheese, and oriental foods as in soy sauce, tempe, hybridization of fruits and plants, waste management which in its years has developed by using microorganisms. ${ }^{11}$ Currently, the utilization of GMO has expanded since it presents a lot of benefits, among others, GMO products are proven to be more resistant towards pest and plant disease, less use of pesticide, attractive appearance of the product, and high nutrition compared to conventional versions. It is claimed that from these positive outcomes, there will be higher possibilities of overcoming global food and population issues. ${ }^{12}$ Therefore, GMO is one of the solution to anticipate food scarcity that is threatening the world, including Indonesia.

According to Nawacita ${ }^{13}$, one of Indonesian government's agendas is to realize economic independence through food sovereignty that is very much affected by GMO products that are safe to consume by Indonesian society. A sub agenda that needs more attention is local provinces' participation amidst realization. In accordance to Forum for Food Sovereignty in 2007, food sovereignty aims to: (1) focus on society's/people's food fulfillment, (2) rewards for food production, (3) development of local food system, (4) placement of food production control in local levels, (5) enhance knowledge and expertise and (6) work in essence with the nature. ${ }^{14}$ To pursue those aims, requiringthe development of a local food system, which in this situation are local regions of every province in Indonesia.

Indonesia has issued several regulations in relation to GMO either in the forms of ministerial decree, joint ministerial decree, government regulation and law to ensure benefits of GMOs safely as a main priority, ${ }^{15}$ whereas in local regions in Indonesia, reinforcement of GMO products ought to be supported by a local certification. Local certification is a form of local government's involvement in food biodiversity's growth that currently focuses on transgenic ${ }^{16}$ food. Government's role is a vital key to

${ }^{10}$ Saragih, Edwin S., et.al. (2001). Ulasan Analisis Regulasi dan Kebijakan Keamanan Hayati dan Peluang Keberhasilan Adopsi Benih Transgenik di Indonesia. Jurnal AgroBiogen, 6 (1), 40-48, DOI: 10.21082/jbio.v6n1.2010, p. 40.

${ }^{11}$ Heller, Knut J. (2003). Genetically Engineered Food Methods and Detection. Germany: Bibliographic Information Published, p. 62.

12 Adlhiyati, Zakki. (2009). Produk Rekayasa Genetika (GMO/Genetically Modified Organism) Sebagai Subjek Perlindungan Paten dan Perlindungan Varietas Tanaman. Tesis Program Magister Ilmu Hukum Universitas .Diponegoro Semarang, p. 1.

${ }^{13}$ Nawacita is President Joko Widodo and Vice President Jusuf Kalla's 9 (nine) prioritized agendas of economic deregulations main targets.

14 Henry Bernstein, Op.Cit., p. 12.

${ }^{15}$ Estiati, Amy., Herman, M. (2015). Regulasi Keamanan Hayati Produk Rekayasa Genetik di Indonesia. Analisis Kebijakan Pertanian, 13 (2), 129-146, DOI: 10.21082/akp.v13n2.2015.129-146 p. 144 .

${ }^{16}$ Transgenic means that one or more DNA sequences from another species have been introduced by artificial means cited from National Human Genome Research Institute, "Genome", National Human Genome Institute. Transgenic. Available from https://www.genome.gov/geneticsglossary/Transgenic. (Accessed on 5 January 2018). 
supporting economic activities for entrepreneurs in the region. However, this would lead to new issues regarding the implementation of GMO products' local certification and commercialization.

Based on the background above, researchers are interested in further discussion on, "Local Certification: Genetically Modified Organisms" Commercialization". Problem identification on this research includes 1) what is the urgency for local certification in GMO products in every region of Indonesia? 2) How is the strategy of the local government utilizing the local certification towards GMO Products of each region in Indonesia?

\section{Method Research}

This is a normative research through a statute approach. Statute approach is used to map and identify regulations in Indonesia in relation to GMO and legal basis for local government authority in regards to agricultural products' concerns.

\section{Result and Discussions}

\subsection{Food Sovereignty and Genetically Modified Organism}

"Food sovereignty" was first introduced in the $2^{\text {nd }}$ international conference from Via Campesina in 1996 at Tlaxcala, Mexico. One of the workgroups in this conference formulates the idea of "food sovereignty". Afterwards in 2007, the Forum formed the concept of food sovereigny for food sovereignty, which was held at the side of Sélingué Lake of Mali, North Africa. This forum succeeds to frame that food sovereignty is people's right towards health and food through an appropriate, environmental-friendly and sustainable method. It also leads to the right to receive food with its agricultural systems. ${ }^{17}$

In Indonesia, The concept of food sovereignty is officially becoming an aim and approach in the national food development in accordance with Law No. 18/2012 on Food, "together in food independency and safety". ${ }^{18}$ Food sovereignty is one of 9 (nine) prioritized government Nawacita's agendas of economic deregulations' main targets. Nawacita is stated by President Joko Widodo in his vision, mission, and action plan entitled, "Jalan Perubahan untuk Indonesia yang Berdaulat, Mandiri, dan Berkepribadian" (Road of Change towards a Sovereign, Independent and Notable Indonesia) i during his presidential election campaign in May 2014. Food Sovereignty is clearly listed in Agenda number 7 (seven) that reads, "mewujudkan kemandirian ekonomi dengan menggerakkan sektor-sektor strategis ekonomi domestic" (realizing economic independency by affecting sectors of domestic economic strategy). This $7^{\text {th }}$ goal includes 5 (five) programs as follows:

a. To raise food sovereignty;

b. To raise energy sovereignty;

c. To raise financial sovereignty;

17 Henry Bernstein, Dianto Bachriadi, Loc.Cit.

18 Syahyuti et.al, Op.Cit.,p. 98 
d. To establish farmers/fishermen and micro, small, average entities including warehouses banks through a post-harvesting management facility in every agricultural/fishing production center; and

e. To realize technology reinforcement through creating a national innovation system policy.

The core of food sovereignty lies with the farmers or in this case also relates to Genetically Modified Organisms (GMO) products by giving attention, support, yielding people the right to freely decide on their agricultural system and establishing food related policies amidst overcoming hunger and poverty. ${ }^{19}$ Besides the right to choose their own plants, farmers have the freedom to apply methods and technology in managing the process of a source into a certain product. Furthermore, food sovereignty actually correlates with trades, natural resources, local knowledge, and concerns on gender equality and insight on organizations. ${ }^{20}$

GMO is basically a set of techniques that are used to manipulate genetic components which is Deoxyribonucleic acid (DNA) genome and genes ${ }^{21}$ that can be performed in 1 (one) cell/organism or from one organism to another, even between different organisms. ${ }^{22}$ Specifically, GMO's existence cannot be ignored in non-genetically engineered agricultural products. ${ }^{23}$ Nevertheless, the main purpose of GMO development is to solve various food scarcity issues that are faced upon the world population, and it will remain unsolved conventionally due to the rapid population growth. ${ }^{24}$

In most cases, utilization of biotechnology that gives certain benefits in encouraging economic growth value (especially) in Indonesia, do not always provide a better impact for the whole related aspect inside it. However, benefits of GMO products could also cause serious negative impacts. For instance, in the agricultural sector, the increase of pesticide production would unconsciously cause continuous harm. In the health sector, medicines of genetically engineered products would provide immunity for certain diseases and cause health effects in the human body. In the environmental aspect, the release of GMOs to nature could cause such disturbance on biodiversity's existence. ${ }^{25}$ Consequently, to avoid possibilities of negative impacts from GMO products, law and

${ }^{19}$ Glipo, A. and F.G. Pascual Jr. (2005). Food sovereignity framework: concept and historical context. Food Sovereignty Framework, Mali: Nyeleni, p. 3.

20 Bourgeois, R., et.al. (2003). Indonesia: Empowering Rural Producers Organization. Rural Development and Natural Resources East Asia and Pacific Region (EASRD). France: CIRAD, p. 12.

${ }^{21}$ Genome and genes are both made of DNA. The difference is that a gene consists of enough DNA to become a protein, whereas a genome is simply the amount of DNA of an organism. U.S. National Library of Medicine. Genetics Home Reference. Available from https://ghr.nlm.nih.gov/. (Accessed on 5 January 2018).

${ }^{22}$ Mahrus. (2014). Kontroversi Produk Rekayasa Genetika Yang Dikonsumsi Masyarakat. Jurnal Biologi Tropis, 14 (2), 108-119, doi:10.29303/jbt.v14i2.138, p. 108.

${ }^{23}$ Koch, Bernhard A. (2007). Economic Loss Caused by Genetically Modified Organisms Liability and Redress for Adventitious Presence of GMOs in Non-GM Crops. Germany: European Centre of Tort and Insurance Law, p. 5.

24 Ibid., p. 109.

${ }^{25}$ Ibid 
other regulation is more than necessary to guarantee the protection and safety of GMO products.

Protection on GMO Variety should qualify new requirements, stable, akin, named, for as long as it fulfills the requirements and provisions of the law, then that variety could be protected and its economic aspect could be taken advantage of. ${ }^{26}$ Therefore, Indonesian Government published regulations as protection on GMO products, as follows: 27

a. Joint (Four) Ministry Decree Year 1999 on Biosafety and Genetically Modified Agricultural Food Product Safety.

b. Law No. 6/1967 on General Provisions of Livestock and Veterinary Health.

c. Law No. 5/1990 on Bio-Natural Resources Conservation and Ecosystem.

d. Law No. 12/1992 on Cultivation.

e. Law No. 16/1992 on Quarantine of Animals, Fishes and Plants.

f. Law No. 5/1994 on Ratification of the United Nations Convention on Biological Diversity (CBD).

g. Law No. 23/1997 on Environmental Management.

h. Law No. 41/1999 on Forestry.

i. Law No. 29/2000 on Plant Variety Protection.

j. Law No. 13/2016 on Patent.

k. Law No. 21/2004 on the Ratification of Cartagena Protocol on Biosafety (CPB).

1. Law No. 18/2012 on Food.

m. Government Regulation No. 6/1995 on Plant Protection.

n. Government Regulation No. 44/1995 on Plant Seedling.

o. Government Regulation No. 21/2005 on Genetically Modified Product Bio-Safety

p. Government Regulation No. 39/2010 on the Commission of Genetically Modified Product Biosafety.

Firmly, the existence of regulations of food requires food, supervision, surveillance, prosecution, and business development facility and certification execution. This is considered very important and is an early foundation to reach food sovereignty in Indonesia, which is one of the Nawacita Government Agendas. The role of local government could be valued from the establishment on food. As an example, the Landak Regency in West Kalimantan Province established a regulation to survey numerous things regarding food in their region. In accordance with Article 3 of Regional Regulation of Landak Regency No. 10/2013 on Food Safety, the scope of food safety includes:28
a. Food availability;
b. Food reserves and land;
c. Food diversities;

\footnotetext{
${ }^{26}$ Lubis, Efridani. (2009). Perlindungan dan Pemanfaatan Sumber Daya Genetik Berdasarkan Penerapan Konsep Sovereign Right dan Hak Kekayaan Intelektual. Bandung: Alumni, p. 109

27 Prianto, Yuwono., Yudhasasmita, Swara. (2017). Tanaman Genetically Modified Organism (GMO) dan Perspektif Hukumnya di Indonesia. AL-KAUNIYAH: Journal of Biology, 10 (2), 133142, doi: 10.15408/kauniyah.v10i2.5264, p. 139.

${ }^{28}$ Regulation of Landak Regency No. 10/2013 on Food Safety.
} 
d. Prevention and countermeasures on food issues;

e. Food price management and safety;

f. Local government's obligations;

g. Rights, obligation and prohibition for society;

h. Elevation of human resources' qualities.

It is clear that local governments are involved and have obligations to manage and survey all aspects that are in correlation with availability, expansion, supervision, prosecution, business development facility on food and food certification fulfillment.

\subsection{The urgency for Local Certification in Genetically Modified Organism (GMO) Product in the Local Government Scope}

A local certification is a form of local government's participation in the development of food sovereignty, which in this focuses on transgenic food. The role of government is a vital supporting aspect for economic issues, especially entrepreneurs in regions. Local certification could ensure a starting step for entrepreneurs to expand their businesses. Local government's support in supervision, surveillance, prosecution, facilitation on food business development, and food certification fulfillment is expected to motivate society in innovating food diversity to bolster primary necessity in Indonesia.

Genetically Modified Organisms (GMO) is a form of Geographical Index that is characterized as a unique commodity in the international trade, even for natural resources products. This particular product is usually found or known in a certain region, area, or country so it could not be found or known in other regions or countries. This commodity is placed as an exclusive-natured product. In the free trade era, this product received a special treatment, which is classsified as Indication of Origin. Article 23 of Trade-Related Aspect of Intellectual Property Rights (TRIPS) Agreement specifically agreed to protect all kinds of products either raw or that are processed through a Geographical Index or Originality System. ${ }^{29}$ The Article motivates patents on GMO products that are categorized as Geographical Index which are a part of the Intellectual Property Rights, especially for regions in Indonesia. Regulation and Government Certification Institution are needed to support GMO technology-based food that is a part of a Geographical Index product in order to enhance national and local economy while also paying attention to the GMO products' quality and food safety.

Patent instructs GMO to be new, contains inventive steps, and possible to be applied to the industry sector so it could be protected by a patent system with the strongest economic aspect compared to others. GMO protection according to Article 7 point (d) of Law No. 14/2001 on Patent clearly regulates the process of microbiology in the patent protection. ${ }^{30}$ Based on this article, a demand on the local certification regulation framework regarding GMO has emerged. Regulation framework as mentioned above is an answer of uncertainty on alignments and supervision intensity towards agricultural

29 Djaja, Hendra. (2013). Perlindungan Indikasi Geografis Pada Produk Lokal Dalam Sistem Perdagangan Internasional. Jurnal Cakrawala Hukum, 18 (2), 136-144, p. 136.

30 Krisnawati, Andriana. Saleh, Gazalba. (2004). Perlindungan Hukum Varietas Tanaman dalam Perspektif Hak Paten dan Hak Pemulia. Jakarta: Raja Grafindo Persada, p. 120. 
parties. Local government's needs on local certification regulation framework regarding GMO is explained as follows: ${ }^{31}$

a. Philosophic base on establishing a local certification is essential to implement the ecocracy concept that is environmental sovereignty or an ecosystem where a government is predicating their governance consistently on ecologically sustainable development principles. This merely aims to realize prosperity amongst society and optimizing local natural resources based on ecologically sustainable development principles.

b. Local certification concept is formulated as an attempt to provide a legal instrument towards the expansion of a GMO product. Local policies of GMO product's data and inventories will be a foundation for the local government to legally guarantee the development of a GMO product. Formulation of local legal instruments is expected to optimize local resource utilization in restoring soil fertility and empowering unfortunate farmers, especially in increasing their incomes and ensuring their prosperity.

c. There is an urgency to issue policy to address fertility aspect of agricultural lands in some areas in Indonesia, including Lampung Province. The present situation shows that there is a lack of organic substance. Another reality is that farmers are growing dependent on inorganic fertilizer in agricultural cultivation, which means a decrease in the farmers' income since inorganic fertilizer costs higher in time and the distribution is often incorrect.

The reasons above convinced the importance of enhancing efforts of GMO food products' protection through establishing a regulation framework and law certainty. Therefore, food certification should be realized both at the national level and in every region of Indonesia.

\subsection{Genetically Modified Organism (GMO) Commercialization and Local Certification Practice}

Since the 1970's, commercialization of GMO products has evolved rapidly across the world. ${ }^{32}$ As time goes by, GMO has been commercialized and is an export-import object in the international trade scope. GMO as an object of the trading system is under the regulation of Sanitary and Phytosanitary (SPS) Agreement, which is an agreement produced by the World Trade Organization (WTO) that underlines human and environmental health through 3 (three) standardizations, codex alimentarius for food, International Plant Protection Convention (IPPC) and World Organization for Animal Health (OIE). ${ }^{33}$ As an approval to ensure intellectual property rights, TRIPS Agreement became a path that is obstacle-free for the execution of GMO commercialization. ${ }^{34}$ Thereafter, Article 1 and 11 of Cartagena Protocol on Biosafety (CPB) explained that GMO is unlikely to be exhibited, commercialized, and benefited by the society if it does

\footnotetext{
${ }^{31}$ Ministry of Agriculture, Directorate of Crops Processing and Marketing, 2017.

${ }^{32}$ Ho, Mae-Wan. (2008). Rekayasa Genetik: Impian atau Petaka. Yogyakarta: Insist Press, p. 27.

33 Davey, Orima Melati. (2018). “Penerapan Precautionary Principle Terhadap Pemanfaatan Genetically Modified Organisms Menurut Cartagena Protocol on Biosafety dan the Sanitary and Phytosanitary Agreement", Final Paper of Law Faculty, Universitas Lampung, p. 5.

34 Zakki Adlhiyati,Op.Cit., p. 151.
} 
not fulfill 2 (two) requirements which are knowledge and qualified scientific evidence. ${ }^{35}$ In another view, GMO products commercialization of several varieties have received support from the international forum even though it is assumed to cause unknown threats, particularly diverse genetic extinctions (especially) in developing countries. ${ }^{36}$

For a developing country such as Indonesia, GMO commercialization is still constrained due to feed, food and environmental licensing. This is as stated by the Director of School of Business (Master Program), Institut Pertanian Bogor (IPB) University, Arief Daryanto. It is also supported by one of Indonesia's company representatives, Corporate Affairs Lead Monsanto Indonesia which declared that until today, this company is doubtful to commercialize GMO's seed until the government gives a green light. ${ }^{37}$ Therefore, protection towards GMO product commercialization from the Indonesian Government is essential, either from our national government or local government through a local certification.

Protection towards GMO is basically aimed to ensure consumer's safety and legal protection upon intellectual property rights from the society or legal entity that are creators of this GMO product. Providing safety to GMO food products is one of the key efforts that shall be achieved through protection and local certification in each created GMO product. Another reason is to prevent the possibility of issues that are harmful and threatening human health. ${ }^{38}$ These possibilities could happen amidst the production, preparation, storage, distribution and utilization of GMO food products. ${ }^{39}$

Regulation framework in regards to feeding with GMO technology product certification is necessary in order to ease food distribution and support economic activities in Indonesia. The success of free trading is decided on a country's ability factor in building a regulation, system and standard which are equivalent to an international regulation, namely a guidance or standard published by the Food and Agricultural Organization (FAO) or World Health Organization (WHO). Another example is provisions on trading partners by the European Union and provisions on human resources forwardness that dominates information rapidly, equipment availability and high production efficiency by the United States of America. ${ }^{40}$ Certification is also directed as a great step in surveying developed GMO products so that their name and origins are archived properly, this would enable the government to monitor progress and give protection to society as consumers in aspects of economy, health, and environment. Besides that, local certification is valued important due to enhancing the development of GMO technology in the food aspect and distribution of local GMO products either nationally or

\footnotetext{
${ }^{35}$ Ferry, Natalie. (2009). Environmental Impact of Genetically Modified Crops. UK: MPG Books Group, p. 329.

${ }^{36}$ Mahrus,Op.Cit., p. 112.

${ }^{37}$ Irene Agustin. Benih Transgenik: Pemerintah Didesak Legalkan GMO Jagung. Available from https://ekonomi.bisnis.com/read/20141006/99/262804/benih-transgenik-pemerintahdidesak-legalkan-gmo-jagung, (Accessed on March 27, 2020).

38 Article 1 Section (3) of Government Regulation No. 21/2005 on Genetically Modified Product Bio-Safety.

${ }^{39}$ Article 1 Section (5) of Government Regulation No. 21/2005 on Genetically Modified Product Bio-Safety.

${ }^{40}$ Santoso et.al. (2009). Pengembangan Sistem Sertifikasi Berbasis Jaminan Mutu dan Keamanan Pangan Produk Udang Ekspor. Buletin PSP, 18 (2), 73-81, p. 74.
} 
internationally in aims to elevate Indonesia's food sovereignty. Nonetheless, it is unfortunate that service execution of certification by the government is still ineffective and even considered rarely realized because currently, this program is not yet seen as fundamental according to general society.

The triumph of GMO products' growth will come true if there is support from the government either in the forms of training, production funding or regulations from each local government. In order to increase the markets' trust, certification programs and its supervision need to be continuously supported and improved by the government or institutions/companies that are aware of GMO product development. Subsequently, Indonesia's certification program will be acknowledged by the world, and our farmers will not have a highly-cost certification. Local certification can be an additional instrument that is fundamental since it is a guarantee from local governments towards production and transgenic feed product. Benefits that could obtain from local certification are: 41

a. Acknowledgement upon the GMO product's worthiness to be marketed;

b. Good and responsible relation standards between the government and companies through the society's perspective;

c. Legalization of GMO product's marketing for distribution.

The importance of regulation and law certainty in food certification is valuable to realize either at the national level or in each region of Indonesia. Regulations and institution establishment for local certification in each region are very much needed to support food activities that require Genetically Modified Organism (GMO) technology, for it could be managed and developed in order to enhance economic activities of the society. Results from regulation and government institution establishment on local certification could guarantee consumers to purchase and use the products that have certification from a $3^{\text {rd }}$ party. A certification institution establishment also provides convenience in the producers' administration while they are fulfilling certification as a demand from consumers before they are willing to consume or purchase food products. As an example, there is an Organic Certification Institution or Lembaga Sertifikasi Organik (LSO) for regions of West Sumatra that was established with purposes of: 42

a. To motivate the progress of licensed organic farmers;

b. To ensure the organic agricultural system is performed according to standards.

c. To contribute in increasing organic certification expenses from farm groups/farmers.

d. To realize prosper farming households.

Moreover, Kebumen Regency in Central Java Province also established a framework that regulates food certification. Article 4 of in Regional Regulation of Kebumen Regency

${ }^{41}$ Global Food Safety Resource. The Importance of Food Safety Certification. Available from https://globalfoodsafetyresource.com/food-safety-certification/. (Accessed on January 28, 2020).

${ }^{42}$ Kementerian Pertanian Direktorat Pengolahan dan Pemasaran Hasil Tanaman Pangan 2017. Lembaga Sertifikasi Organis (LSO) Propinsi Sumatera Barat: Satu-satunya LSO Pemerintah, Available from http://pphtp.tanamanpangan.pertanian.go.id/berita/85. (Accessed on November 7, 2018). 
No. 17/2017 on Food Safety Surveillance defines the scope of food safety surveillance, as follows:

a. Supervision, surveillance, prosecution and facilitation of fresh food business development to fulfill minimum technical requirements on food safety;

b. Execution on processed food certification for fast food businesses and household food industry;

c. Supervision and surveillance on fast food businesses and household food industry;

d. Performing inspection if there are violation allegations on fast food businesses and household food industry;

Regulation of Kebumen Regency No. 17/2017 on Food Safety Surveillance has enlightened that certification by the local government is essential to promote the growth and expansion of the economic sector from products of GMO technology in food fields. This regional regulation is considered as a guideline to formulate other local policies regarding local certification that must be taken in events of GMO product inventory, scopes of regulations and implementation of GMO product's safety.

Furthermore, "Hygienic and Safe Certification and Labeling of Processed Fast Food" has been executed by Badan Pengawas Obat dan Makanan (BPOM) or National Drug and Food Control Agency of Palembang in accordance with the Government of Palembang City (POSS HA) in Dock Point of Benteng Kuto Besak (BKB), Palembang to minimize food and beverage distribution with a harmful substance. In this opportunity, the Head of BPOM Palembang stated, every businessman that ought to be certified, must first own facilities such as restaurants and catering with training students in employment. ${ }^{43}$

\section{Conclusion}

Genetically Modified Organism or GMO is a way to reach Indonesia's food sovereignty, by giving attention, support, yielding people the right to freely decide on their agricultural system and establishing food-related policies amidst overcoming hunger and poverty. GMO commercialization is still constrained by permits on feed, food and environmental safety. Local certification in each region are very much needed to support food activities that require Genetically Modified Organism (GMO) technology, for it could be managed and developed in order to enhance economic activities of society Moreover, Local certification in every region is very much needed to bolster food production with GMO technology base as part of Geographical Index product. In the implementation amongst society, the product could be supervised and developed to enhance local and national economic activities by emphasizing the quality of genetically modified products and its food safety. The Indonesian Government's protection on GMO product commercialization is required, both from national and local government through a local certification. Practice upon food local certification is implemented in several regions of Indonesia, such as West Sumatra by establishing an institution, Kebumen Regency by forming a food certification-related regulation, and Palembang City also by applying food certification. Therefore, every region in Indonesia is expected

43 Are. BPOM - Pemkot Palembang Kerjasama Sertifikasi Pedagang dan Pelaku Usaha Makanan Siap Saji. Available from https://sumateranews.co.id/bpom-pemkot-palembang-kerjasamasertifikasi-pedagang-dan-pelaku-usaha-makanan-siap-saji/, (Accessed on March 7, 2020). 
to apply this strategy and support progressive national food sovereignty through GMO product's local certification.

\section{References}

\section{$\underline{\text { Books }}$}

Andriana Krisnawati \& Gazalba Saleh. (2004). Perlindungan Hukum Varietas Tanaman dalam Perspektif Hak Paten dan Hak Pemulia. Jakarta: Raja Grafindo Persada

Bourgeois, R., F. Jesus, M. Roesch, N. Soeprapto, A. Renggana, and A. Gouyon. (2003). Indonesia: Empowering Rural Producers Organization. Rural Development and Natural Resources East Asia and Pacific Region (EASRD). France: CIRAD.

FAO Office for Corporate Communication. (2019). FAO Publication Catalogue 2019 March. Italy: FAO Publication.

Ferry, Natalie. (2009). Environmental Impact of Genetically Modified Crops. UK: MPG Books Group.

Heller, Knut J. (2003). Genetically Engineered Food Methods and Detection, Germany: Bibliographic Information Published.

Henry Bernstein, Dianto Bachriadi. (2014). Tantangan Kedaulatan Pangan, Bandung: ARC Books.

Ho, Mae-Wan.(2008).Rekayasa Genetik: Impian atau Petaka. Yogyakarta: Insist Press.

Koch, Bernhard A. (2007). Economic Loss Caused by Genetically Modified Organisms Liability and Redress for Adventitious Presence of GMOs in Non-GM Crops. Germany: European Centre of Tort and Insurance Law.

Lubis, Efridani. (2009). Perlindungan dan Pemanfaatan Sumber Daya Genetik Berdasarkan Penerapan Konsep Sovereign Right dan Hak Kekayaan Intelektual.Bandung: Alumni,

Rifkin, Jeremy. (1998). The Biotech Century: How Genetic Commerce Will Change the World. London: Phoenix.

Wu, Felicia. (2004). The Future of Genetically Modified Crops Lessons from the Green Revolution. Santa Monica: Rand Corporation.

\section{Journals}

Djaja, Hendra. (2013). Perlindungan Indikasi Geografis Pada Produk Lokal Dalam Sistem Perdagangan Internasional. Jurnal Cakrawala Hukum, 18 (2), 136-144.

Estiati, Amy., Herman, M. (2015). Regulasi Keamanan Hayati Produk Rekayasa Genetik di Indonesia. Analisis Kebijakan Pertanian, 13 (2), 129-146, DOI: 10.21082/akp.v13n2.2015.129-146.

Farid, Abdul., Romadi, Ugik., Witono, Djoko. (2018). Faktor- Faktor yang Mempengaruhi Adopsi Petani dalam Penerapan Sistem Tanam Jajar Legowo di Desa Sukosari Kecamatan Kasembon Kabupaten Malang Provinsi Jawa Timur. Jurnal Penyuluhan, 4 (1), 27-32, doi: 10.25015/ penyuluhan.v14i1.19226.

Glipo, A. and F.G. Pascual Jr. (2005). Food sovereignity framework: concept and historical context. Food Sovereignty Framework, Mali: Nyeleni.

Mahrus. (2014). Kontroversi Produk Rekayasa Genetika Yang Dikonsumsi Masyarakat. Jurnal Biologi Tropis, 14 (2), 108-119, doi:10.29303/jbt.v14i2.138,

Prianto, Yuwono., Yudhasasmita, Swara. (2017). Tanaman Genetically Modified Organism (GMO) dan Perspektif Hukumnya di Indonesia. Al-Kauniyah: Journal of Biology, 10 (2), 133-142, doi: 10.15408/kauniyah.v10i2.5264. 
Santoso et.al. (2009). Pengembangan Sistem Sertifikasi Berbasis Jaminan Mutu dan Keamanan Pangan Produk Udang Ekspor. Buletin PSP, 18 (2), 73-81.

Saragih, Edwin S., et.al. (2001). Ulasan Analisis Regulasi dan Kebijakan Keamanan Hayati dan Peluang Keberhasilan Adopsi Benih Transgenik di Indonesia. Jurnal AgroBiogen, 6 (1), 40-48, DOI: 10.21082/jbio.v6n1.2010.

Syahyuti, et.al. (2015). Kedaulatan Pangan Sebagai Basis Untuk Mewujudkan Ketahanan Pangan Nasional. Forum Penelitian Agro Ekonomi, 33 (2), 95-109, doi: 10.21082/fae.v33n2.2015.95-109.

\section{Proceeding, Thesis and Scientific Papers}

Adlhiyati, Zakki. (2009). Produk Rekayasa Genetika (GMO/Genetically Modified Organism) Sebagai Subjek Perlindungan Paten dan Perlindungan Varietas Tanaman. Tesis Program Magister Ilmu Hukum Universitas Diponegoro Semarang.

Davey, Orima Melati. (2018). Penerapan Precautionary Principle Terhadap Pemanfaatan Genetically Modified Organisms Menurut Cartagena Protocol on Biosafety dan the Sanitary and Phytosanitary Agreement. Skripsi Fakultas Hukum Universitas Lampung.

Sutarno. (2016). Rekayasa Genetik Dan Perkembangan Bioteknologi di Bidang Peternakan. Proceeding Biology Education Conference, 13 (1), 23-27.

\section{Online/World Wide Web}

Dinas Pertanian, Perikanan, dan Kehutanan Kota Pontianak. Tanaman Transgenik, Solusi atau Polusi?. Available from http://pertanian.pontianakkota.go.id/artikel/23tanaman-transgenik-solusi-ataupolusi.html. (Accessed on 5 January 2018).

Irene Agustin. Benih Transgenik: Pemerintah Didesak Legalkan GMO Jagung. Available from https://ekonomi.bisnis.com/read/20141006/99/262804/benih-transgenikpemerintah-didesak-legalkan-gmo-jagung, (Accessed on March 27, 2020).

Global Food Safety Resource. The Importance of Food Safety Certification. Available from https://globalfoodsafetyresource.com/food-safety-certification/. (Accessed on January 28, 2020).

Kementerian Pertanian Direktorat Pengolahan dan Pemasaran Hasil Tanaman Pangan 2017. Lembaga Sertifikasi Organis (LSO) Propinsi Sumatera Barat: Satu-satunya LSO Pemerintah, Available from http://pphtp.tanamanpangan.pertanian.go.id/berita/85. (Accessed on November 7,2018$)$.

\section{$\underline{\text { Regulations }}$}

Government Regulation No. 21/2005 on Genetically Modified Product Bio-Safety. Ministry of Agriculture, Directorate of Crops Processing and Marketing, 2017. Regional Regulation of Landak Regency No. 10/2013 on Food Safety. 